\title{
Using extracellular polymeric substances (EPS)- producing cyanobacteria for the bioremediation of heavy metals: do cations compete for the EPS functional groups and also accumulate inside the cell?
}

\author{
Sara Pereira, ${ }^{1,2} \uparrow$ Ernesto Micheletti, ${ }^{3} \dagger$ Andrea Zille, ${ }^{1}$ Arlete Santos, ${ }^{1,2}$ \\ Pedro Moradas-Ferreira, ${ }^{1,4}$ Paula Tamagnini ${ }^{1,2}$ and Roberto De Philippis ${ }^{3}$ \\ ${ }^{1}$ IBMC - Instituto de Biologia Molecular e Celular, Universidade do Porto, Rua do Campo Alegre \\ 823, 4150-180 Porto, Portugal \\ ${ }^{2}$ Faculdade de Ciências, Universidade do Porto, Departamento de Biologia, Rua do Campo Alegre, \\ ${ }^{3}$ Department of Agricultural Biotechnology, University of Florence, Piazzale delle Cascine 24, \\ I-50144, Florence, Italy \\ ${ }^{4}$ Instituto de Ciências Biomédicas Abel Salazar (ICBAS), Universidade do Porto, Largo Abel Salazar \\ 2, 4099-003 Porto, Portugal
}

\begin{abstract}
Many cyanobacteria produce extracellular polymeric substances (EPS) mainly of polysaccharidic nature. These EPS can remain associated to the cell surface as sheaths, capsules and/or slimes, or be liberated into the surrounding environment as released polysaccharides (RPS). The ability of EPS-producing cyanobacteria to remove heavy metals from aqueous solutions has been widely reported in the literature, focusing mainly on the biotechnological potential. However, the knowledge of the effects of the metals in the cell's survival/growth is still scarce, particularly when they are simultaneously exposed to more than one metal. This work evaluated the effects of different concentrations of $\mathrm{Cu}^{2+}$ and/or $\mathrm{Pb}^{2+}$ in the growth/survival of Gloeothece sp. PCC 6909 and its sheathless mutant Gloeothece sp. CCY 9612. The results obtained clearly showed that both phenotypes are more severely affected by $\mathrm{Cu}^{2+}$ than $\mathrm{Pb}^{2+}$, and that the mutant is more sensitive to the former metal than the wild-type. Evident ultrastructural changes were also observed in the wild-type and mutant cells exposed to high levels $\left(10 \mathrm{mg} \mathrm{l}^{-1}\right)$ of $\mathrm{Cu}^{2+}$. Moreover, in bi-metal systems, $\mathrm{Pb}^{2+}$ was preferentially removed compared with $\mathrm{Cu}^{2+}$, being the RPS of the mutant that is the most efficient polysaccharide fraction in metal removal. In these systems, the simultaneous presence of $\mathrm{Cu}^{2+}$ and $\mathrm{Pb}^{2+}$ caused a mutual inhibition in the adsorption of each metal.
\end{abstract}

Received 30 April 2010

Revised 18 October 2010

Accepted 20 October 2010

\section{INTRODUCTION}

Cyanobacteria can be found in almost any ecological niche from fresh and salt water to terrestrial and extreme environments, including metal-contaminated habitats (Burnat et al., 2009; Kiran et al., 2008). Most of the strains are able to produce extracellular polymeric substances (EPS) mainly of polysaccharidic nature. The EPS can

†These authors contributed equally to this work.

Abbreviations: EPS, extracellular polymeric substances; mt, mutant; RPS, released polysaccharides; TEM, transmission electron microscopy; wt, wild-type.

A supplementary figure is available with the online version of this paper. remain associated to the cell surface as sheaths, capsules and/or slimes, or be liberated into the surrounding environment as released polysaccharides (RPS) (De Philippis \& Vincenzini, 2003; Pereira et al., 2009). The EPS serve as a boundary between the cyanobacterial cell and its immediate environment. Many putative roles have been proposed for these polymers, such as protection against dehydration or UV radiation, biomineralization and phagocytosis. It has also been postulated that EPS confer on the cyanobacteria the ability to adhere to solid substrates, as well as facilitate the locomotion of gliding strains. Moreover, the overall negative charge of cyanobacterial EPS may be essential for sequestering metal cations that are essential for cell growth but present at low 
concentrations in their surroundings, and/or preventing the direct contact between the cells and toxic heavy metals dispersed in the environment (De Philippis \& Vincenzini, 2003; Pereira et al., 2009). The ability of EPS-producing cyanobacteria to remove heavy metals from aqueous solutions has been widely reported in the literature, focusing mainly on its biotechnological potential (De Philippis et al., 2001, 2007; De Philippis \& Micheletti, 2009; De Philippis \& Vincenzini, 2003; Li et al., 2001). On the other hand, information about the effects of the metals on the physiology of cyanobacteria is still scarce particularly for situations of simultaneous exposure to more than one metal, which frequently occur in polluted environments (Baptista \& Vasconcelos, 2006; Burnat et al., 2009; Fiore \& Trevors, 1994; Heng et al., 2004). From the physiological point of view, metals can be grouped into two main categories: (i) essential (e.g. $\mathrm{Ca}, \mathrm{Mg}, \mathrm{Fe}, \mathrm{Zn}$ and $\mathrm{Cu}$ ) and (ii) non-essential to life, i.e. without any known biological function (e.g. $\mathrm{Hg}, \mathrm{Cd}$ and $\mathrm{Pb}$ ) (Ishaque et al., 2006). However, when in excess, even the essential ones may become toxic to the cells (Lewinson et al., 2009; Valls \& de Lorenzo, 2002). Cyanobacteria can decrease metal uptake by sequestering the metals ions in their extracellular surfaces and/or by releasing ligands to the surrounding environment. Once the metals ions enter the cell, their toxicity can be avoided by their reduction to a less toxic oxidation state, intracellular complexing (e.g. metallothioneins) or metal efflux by export systems, e.g. P-type ATPases (Baptista \& Vasconcelos, 2006; Nies, 1999; Roy et al., 2008). When these protection mechanisms fail, the cell experiences the toxic effects of high metal concentration that can cause the disintegration and disorganization of thylakoid membranes, large intrathylakoidal spaces, increase of polyphosphate bodies and even cell death (Baptista \& Vasconcelos, 2006; Nies, 1999).

A previous study tested the capability of the unicellular cyanobacterium Gloeothece sp. PCC 6909 and its sheathless mutant Gloeothece sp. CCY 9612 (obtained by random chemical mutagenesis and still largely uncharacterized) to remove copper ions from aqueous solutions, and demonstrated that specific binding sites for $\mathrm{Cu}^{2+}$ were present in the sheath of the wild-type and in the RPS of both the wildtype and the mutant, with the RPS of the mutant being the more effective polymer (Micheletti et al., 2008b). The aim of this work was to evaluate the effects of different concentrations of $\mathrm{Cu}^{2+}$ and/or $\mathrm{Pb}^{2+}$ in the growth/survival of the two phenotypes, as well as changes in their ultrastructure. In addition, their capability to remove $\mathrm{Cu}^{2+}$ and/or $\mathrm{Pb}^{2+}$ from bi-metal systems, and the affinity of the various culture fractions for each metal ion were assessed.

\section{METHODS}

Organisms and growth conditions. Gloeothece sp. PCC 6909 wild-type (Pasteur Culture Collection) and its sheathless mutant Gloeothece sp. CCY 9612 (obtained by chemical mutagenesis using nitrosoguanidine, S. Shestakov, Moscow, Russia, and provided by L. Stal, CYY - Culture Collection of Yerseke, The Netherlands) were grown in BG11 $1_{0}$ (Rippka et al., 1979) supplemented with $0.375 \mathrm{~g}$ $\mathrm{NaNO}_{3} \mathrm{l}^{-1}$, in an orbital shaker at 80 r.p.m. at $25^{\circ} \mathrm{C}$, under a $16 \mathrm{~h}$ light $\left[10 \mu \mathrm{mol}\right.$ photons (photosynthetic active radiation; PAR) $\mathrm{m}^{-2}$ $\mathrm{s}^{-1}$ ]/ $8 \mathrm{~h}$ dark regimen, unless stated otherwise.

Growth curves. Gloeothece wild-type (wt) and sheathless mutant (mt) were grown in the medium mentioned above (control) or in the same medium supplemented with different concentrations of copper $\left(\mathrm{Cu}^{2+}\right)$ and/or lead $\left(\mathrm{Pb}^{2+}\right)$. For mono-metal solutions, media were supplemented with $0.05,0.10,0.30,0.50,0.70$ and $1.0 \mathrm{mg} \mathrm{Cu}^{2+} 1^{-1}(0.8,1.6,4.7$, $7.9,11.0$ and $15.7 \mu \mathrm{M}$, respectively) or $10,20,30,40$ and $50 \mathrm{mg} \mathrm{Pb}^{2+} \mathrm{l}^{-1}$ (48.3, 96.5, 144.8, 193.1 and $241.3 \mu \mathrm{M}$, respectively) (stock solutions $10000 \mu \mathrm{g} \mathrm{ml}^{-1}$ in $2 \% \mathrm{HNO}_{3}$, Sigma-Aldrich). For bi-metal solutions, the medium was supplemented with $0.10 \mathrm{mg} \mathrm{Cu}^{2+} \mathrm{l}^{-1}$ and $10 \mathrm{mg} \mathrm{Pb}^{2+}$ $1^{-1}, 0.10 \mathrm{mg} \mathrm{Cu}^{2+} 1^{-1}$ and $20 \mathrm{mg} \mathrm{Pb}^{2+} 1^{-1}$, or $0.30 \mathrm{mg} \mathrm{Cu}^{2+} 1^{-1}$ and $20 \mathrm{mg} \mathrm{Pb}^{2+} 1^{-1}$. Growth measurements were performed by monitoring $\mathrm{OD}_{730}$ with a SmartSpec3000 spectrophotometer (Bio-Rad). The correlation between optical density and protein concentration was $\mathrm{OD}_{730} 0.5: 170 \mu \mathrm{g}$ protein $\mathrm{ml}^{-1}$ for the wild-type, and $\mathrm{OD}_{730}$ $0.5: 112 \mu \mathrm{g}$ protein $\mathrm{ml}^{-1}$ for the mutant. Protein extraction and quantification, using the BCA protein assay, were performed as described previously (Leitão et al., 2005). The total carbohydrate content was measured by using the phenol-sulphuric acid method (Dubois et al., 1956) in samples withdrawn from 10- and 30-day-old cultures.

Transmission electron microscopy (TEM). Gloeothece wt and $\mathrm{mt}$ cells were collected by centrifugation and processed as described by Seabra et al. (2009). Sections were examined using a Zeiss EM C10 electron microscope operating at $80 \mathrm{kV}$, and unstained sections (without uranyl acetate and lead citrate) were used as controls. In the controls, the post-fixation with osmium tetroxide was kept in order to preserve and contrast the membranes.

Removal assays in mono-metal and bi-metal systems. Gloeothece wt and mt cultures grown at $30{ }^{\circ} \mathrm{C}$ and under continuous illumination provided by cool white fluorescent tubes $[100 \mu \mathrm{mol}$ photons (PAR) $\mathrm{m}^{-2} \mathrm{~s}^{-1}$ ] were placed in dialysis tubes $(12-14 \mathrm{kDa}$ of molecular weight cut-off; Medicell International) and dialysed before and after a pre-treatment with $0.1 \mathrm{M} \mathrm{HCl}$ as described previously (Micheletti et al., 2008b). Subsequently, $30 \mathrm{ml}$ confined dialysed cultures were incubated in $80 \mathrm{ml}$ aqueous solutions containing $10 \mathrm{mg}$ $1^{-1} \mathrm{Cu}^{2+}$ or $\mathrm{Pb}^{2+}$ (mono-metal systems) or $10 \mathrm{mg} \mathrm{l}^{-1}$ each metal (bimetal system) for at least $24 \mathrm{~h}$. The $\mathrm{pH}$ of the system (biosorbent + metal solution) was adjusted to 4.5-5.5. The final metal content was determined with an atomic absorption spectrophotometer (SpectrAA 10 plus, Varian) operating at wavelengths of 232 and $283.3 \mathrm{~nm}$ for $\mathrm{Cu}^{2+}$ and $\mathrm{Pb}^{2+}$ quantification, respectively. The amount of metal removed from the aqueous solution was calculated as the difference in the metal concentration before and after contact with the cultures, using a blank obtained by adding $30 \mathrm{ml}$ confined distilled water $(\mathrm{pH} 4.5-5.5)$ to $80 \mathrm{ml}$ metal solution. Specific metal removal (q), expressed as (mg metal removed) ( $\mathrm{g}$ dry weight) ${ }^{-1}$ was calculated as: $q\left(\mathrm{mg} \mathrm{g}^{-1}\right)=V\left(C_{\mathrm{i}}-C_{\mathrm{f}}\right) m^{-1}$, where $V$ is the sample volume $(\mathrm{l}), C_{\mathrm{i}}$ and $C_{\mathrm{f}}$ are the initial and final metal concentrations $\left(\mathrm{mg} \mathrm{l}^{-1}\right)$, respectively, and $m$ is the amount ( $\mathrm{g}$ ) of dry biomass (Volesky \& MayPhillips, 1995). The dry weight $\left(\mathrm{g} \mathrm{l}^{-1}\right)$ was determined by vacuum filtration of $10 \mathrm{ml}$ of the dialysed cultures, followed by drying the filter at $50{ }^{\circ} \mathrm{C}$ until a constant weight was reached, and the amount of carbohydrates was determined as described above. In order to determine the contribution of each fraction of the culture to the removal of $\mathrm{Cu}^{2+}$ and $\mathrm{Pb}^{2+}$ ions, metal removal assays were performed in parallel with dialysed whole cultures (biomass + RPS), isolated biomass or isolated RPS suspended in deionized water at $\mathrm{pH}$ 4.5-5.5. For this purpose, the carbohydrate content of each fraction was determined as described above, and the specific metal removal 
efficiencies were expressed as (mg metal removed) (g carbohydrates present in the biosorbent $)^{-1}$.

Sequential metal removal assays. To assess the efficiency of the isolated biomass in the removal of $\mathrm{Cu}^{2+}$ after a previous exposure to $\mathrm{Pb}^{2+}$ and vice versa, removal assays were performed as described above, with the following modifications: after the incubation of the confined biomass in a solution containing the first metal, the biosorbent was dialysed against deionized water at $\mathrm{pH} 4.5-5.5$ for at least $16 \mathrm{~h}$, and transferred to the solution containing the second metal. The amount of metal released into the second metal solution was also determined by atomic absorption spectroscopy.

\section{RESULTS}

\section{Effects of $\mathrm{Cu}^{2+}$ and $\mathrm{Pb}^{2+}$ on the growth/survival of Gloeothece cells}

Cultures of Gloeothece wt and $\mathrm{mt}$ were grown in BG11 supplemented with $0.375 \mathrm{~g} \mathrm{NaNO}_{3} \mathrm{l}^{-1}$ (control) or medium supplemented with different concentrations of $\mathrm{Cu}^{2+}$ and/or $\mathrm{Pb}^{2+}$. The data presented in Fig. 1 show that generally the mutant grows faster than the wild-type. For both organisms, the growth was negatively affected by the presence of the metal(s), with increasing concentrations leading to a gradual decrease in growth (Fig. 1). Both the wild-type and mutant were considerably more susceptible to $\mathrm{Cu}^{2+}$ than to $\mathrm{Pb}^{2+}$. The presence of 0.5 (mutant) or 1.0 (wild-type) $\mathrm{mg} \mathrm{Cu}^{2+} 1^{-1}$ in the culture medium led to apparent cell death, whereas for $\mathrm{Pb}^{2+}$, similar effects were only observed for metal concentrations of 40 or $50 \mathrm{mg} \mathrm{l}^{-1}$ (Fig. 1a-d). The wild-type grew to a similar extent with $0.05,0.1$ and $0.3 \mathrm{mg} \mathrm{Cu} \mathrm{Cu}^{2+}$; therefore, this last growth curve was omitted from the graph. The growth curves with 0.5 and $0.7 \mathrm{mg} \mathrm{Cu}^{2+} \mathrm{l}^{-1}$, and the respective control, are shown as an insert since these data are from a separate experiment. Interestingly, the growth of the mutant was transiently arrested for lower concentrations of copper $\left[0.05 \mathrm{mg} \mathrm{l}^{-1}\right.$ (data not shown) 0.1 and $0.3 \mathrm{mg} \mathrm{l}^{-1}$ ], resuming after approximately 10 days (Fig. 1d), while such an effect was not observed for the wild-type. When the cells were exposed to $\mathrm{Pb}^{2+}$, the decrease in the growth rate was higher for the wild-type. When the wild-type and mutant were exposed to the simultaneous presence of both metals $\left(0.1 \mathrm{mg} \mathrm{Cu}{ }^{2+} 1^{-1}+10 \mathrm{mg} \mathrm{Pb}^{2+} 1^{-1}\right.$ and $0.1 \mathrm{mg} \mathrm{Cu}{ }^{2+}$ $\mathrm{l}^{-1}+20 \mathrm{mg} \mathrm{Pb}^{2+} \mathrm{l}^{-1}$ ) their growth decreased compared with growth in cultures supplemented with one of the metals at the same concentration; this effect was more noticeable for the mutant (Fig. 1c-f). When the cells were exposed to $0.3 \mathrm{mg} \mathrm{Cu}{ }^{2+} \mathrm{l}^{-1}+20 \mathrm{mg} \mathrm{\textrm {Pb } ^ { 2 + }} \mathrm{l}^{-1}$, their growth followed a
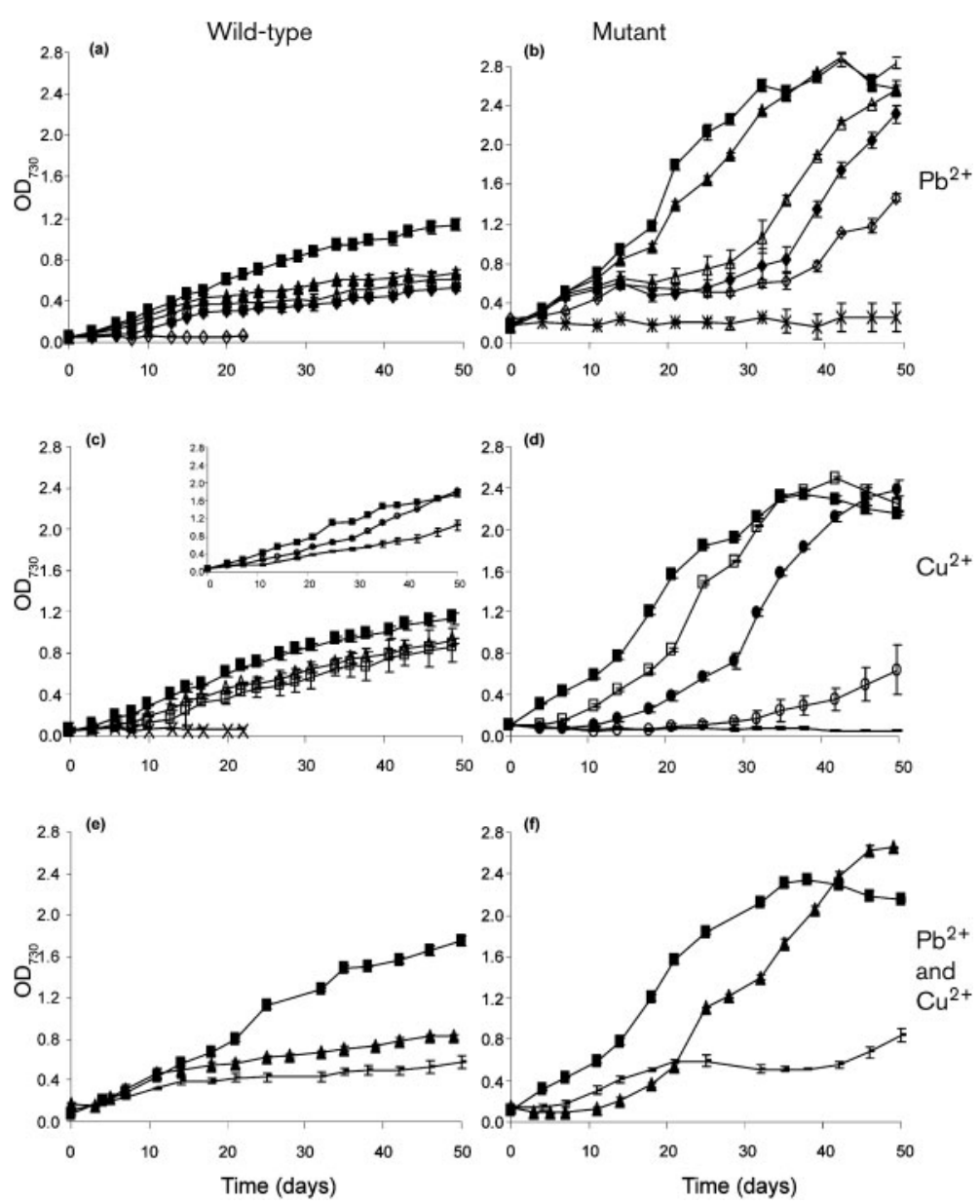

Fig. 1. Growth curves of Gloeothece sp. PCC 6909 wild-type (a, c, e) and its sheathless mutant (b, d, f) Gloeothece sp. CCY 9612 in $\mathrm{BG} 11$ 。 medium $+0.375 \mathrm{~g} \mathrm{NaNO}_{3} \mathrm{I}^{-1}(\boldsymbol{\square})$, with different concentrations of $\mathrm{Pb}^{2+}(\mathrm{a}, \mathrm{b})$ or $\mathrm{Cu}^{2+}(\mathrm{c}, \mathrm{d})$, and with $\mathrm{Pb}^{2+}$ plus $\mathrm{Cu}^{2+}(\mathrm{e}, \mathrm{f})$. Media were supplemented with $10(\boldsymbol{\Delta}), 20$ $(\triangle), 30(\diamond), 40(\diamond)$ or $50\left(^{*}\right) \mathrm{mg} \mathrm{Pb}{ }^{2+} \mathrm{I}^{-1}(\mathrm{a}$, b), $0.05(\nabla), 0.10(\square), 0.30(\bigcirc), 0.50(\bigcirc)$, $0.70(-)$ or $1.00(\times) \mathrm{mg} \mathrm{Cu}^{2+} \mathrm{I}^{-1}(\mathrm{c}, \mathrm{d}), 10 \mathrm{mg}$ $\mathrm{Pb}^{2+} \mathrm{I}^{-1}$ plus $0.1 \mathrm{mg} \mathrm{Cu}^{2+} \mathrm{I}^{-1}(\mathbf{\Delta})$ or $20 \mathrm{mg}$ $\mathrm{Pb}^{2+} \mathrm{I}^{-1}$ plus $0.1 \mathrm{mg} \mathrm{Cu}^{2+} \mathrm{I}^{-1}(-)(\mathrm{e}, \mathrm{f})$. Data are means \pm SD $(n=3)$. Inset in (c) shows the growth curves with 0.5 and $0.7 \mathrm{mg} \mathrm{Cu}^{2+} \mathrm{I}^{-1}$, and the respective control, since these data are from a separate experiment. 
similar pattern to that observed for $0.1 \mathrm{mg} \mathrm{Cu}^{2+} \mathrm{l}^{-1}+20 \mathrm{mg}$ $\mathrm{Pb}^{2+} \mathrm{l}^{-1}$ (data not shown). The total carbohydrate content was measured for 10- and 30-day-old cultures, and the values obtained follow the pattern of the growth curves (data not shown).

\section{Ultrastructural changes and sites of metal accumulation}

TEM studies were performed in order to investigate the sites of metal accumulation, as well as possible structural changes occurring in Gloeothece wild-type and mutant cells (Fig. 2). When the wild-type and mutant were exposed to sublethal metal concentrations (Fig. 2c, d, g, h), no major ultrastructural changes were observed, including in the arrangement of the thylakoid membranes. However, regardless of the metal, the number of intracellular inclusions generally increased compared with the controls (Fig. 2a, b). When the wild-type and mutant cells were exposed to $10 \mathrm{mg} \mathrm{Cu}^{2+}$ $1^{-1}$, a large number of cells were severely damaged and apparently dead (Fig. 2e, f inserts). As expected, large amounts of metal ions, either $\mathrm{Pb}^{2+}$ or $\mathrm{Cu}^{2+}$, were adsorbed to the sheath of the wild-type (Fig. 2c, e, g, arrowheads). In contrast, for the cells of the mutant, and since the RPS were removed during the sample processing for TEM, only intracellular accumulations can be perceived. In fact, electron-dense deposits can be observed in vacuolar structures of the mutant cells exposed to either $\mathrm{Pb}^{2+}$ or $\mathrm{Cu}^{2+}$ (Fig. 2d, f, dashed arrows). Moreover, cytoplasmic electron-dense deposits could be discerned in the cells of the wild-type and mutant exposed to $\mathrm{Cu}^{2+}$ (Fig. 2e-h, full arrows). Controls without uranyl acetate and lead citrate (unstained sections) are shown in Supplementary Fig. S1 (available with the online version of this paper).

\section{Affinity of culture fractions for $\mathbf{C u}^{2+}$ and $\mathbf{P b}^{2+}$}

The specific metal removal $q$ [expressed as (mg metal removed) ( $\mathrm{g}$ dry biomass) ${ }^{-1}$ ] was determined in mono- and bi-metal systems. When whole cultures (biomass + RPS) of the wild-type and mutant were in contact with $\mathrm{Cu}^{2+}$ and/or $\mathrm{Pb}^{2+}$, the specific metal removal was generally higher for the mutant. Both the wild-type and the mutant showed higher $q$ values for $\mathrm{Pb}^{2+}$ than $\mathrm{Cu}^{2+}$ (Table 1). The simultaneous presence of the two cations caused a decrease in the removal of each metal. $\mathrm{Cu}^{2+}$ removal decreased by $47.2 \%$ for the wild-type and $65.4 \%$ for the mutant, whereas the $\mathrm{Pb}^{2+}$ removal decreased by 13.8 and $39.8 \%$ respectively. The contribution of each culture fraction to metal removal was also evaluated. In both the mono- and bi-metal systems, the isolated biomass of Gloeothece wild-type was more effective in metal removal than the biomass of the mutant, particularly for $\mathrm{Cu}^{2+}$, whereas the isolated RPS of the mutant consistently removed larger amounts of metals than those of the wild-type (Table 1). Mutual inhibition of metal binding, which was invariably more accentuated for $\mathrm{Cu}^{2+}$, was also observed for the isolated biomass and RPS of both organisms, and was particularly evident for the biomass of

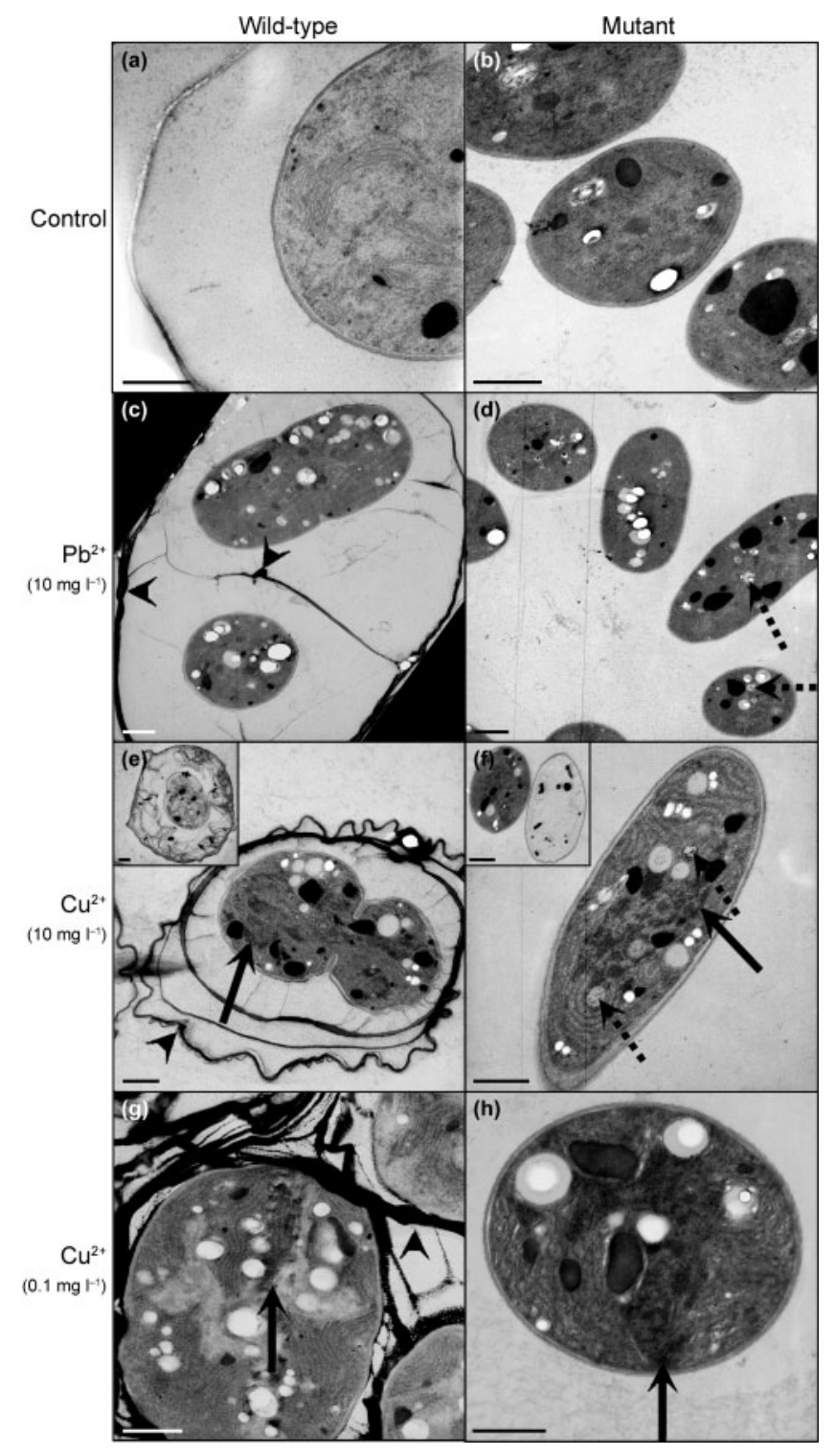

Fig. 2. TEM of Gloeothece sp. PCC 6909 wt (a, c, e, g) and mt Gloeothece sp. CCY 9612 (b, d, f, h) in BG11。 medium + $0.375 \mathrm{~g}$ $\mathrm{NaNO}_{3} I^{-1}(a, b)$, or in the same medium supplemented with $10 \mathrm{mg} \mathrm{Pb}^{2+} \mathrm{I}^{-1}$ (c, d), $10 \mathrm{mg} \mathrm{Cu}^{2+} \mathrm{I}^{-1}(\mathrm{e}, \mathrm{f})$ or $0.1 \mathrm{mg} \mathrm{Cu}^{2+} \mathrm{I}^{-1}$ $(g, h)$. Samples were withdrawn from cultures after $24 \mathrm{~h}(\mathrm{a}-\mathrm{f})$ or 10 days $(\mathrm{g}, \mathrm{h})$. Inserts show severely damaged and/or dead cells. Arrowheads, metal accumulation in the EPS; full arrows, metal accumulation in the cytoplasm; dashed arrows, accumulation in vesicular structures. Bars, $1 \mu \mathrm{m}$.

the mutant where the inhibition of $\mathrm{Cu}^{2+}$ removal was complete. In addition, the inhibition of $\mathrm{Pb}^{2+}$ or $\mathrm{Cu}^{2+}$ adsorption in the bi-metal system was more accentuated for the mutant compared with the wild-type.

In order to further evaluate the different affinities of the isolated biomasses of the wild-type and mutant for $\mathrm{Cu}^{2+}$ and $\mathrm{Pb}^{2+}$, sequential metal removal assays were performed (Table 2). The results obtained revealed that, regardless of 
Table 1. Specific metal removal $(q)$ and inhibition of metal sorption from mono-metal $\left(\mathrm{Cu}^{2+}\right.$ or $\left.\mathrm{Pb}^{2+}\right)$ or bi-metal $\left(\mathrm{Cu}^{2+}+\mathrm{Pb}^{2+}\right)$ solutions using whole cultures, isolated biomass or isolated RPS of Gloeothece sp. PCC 6909 (wt) or Gloeothece sp. CCY 9612 (mt)

Data are means $\pm \mathrm{SD}(n=3)$. Both the wild-type and the mutant showed higher $q$ values for $\mathrm{Pb}^{2+}$ than $\mathrm{Cu}^{2+}$ (bold type).

\begin{tabular}{|c|c|c|c|c|c|c|c|}
\hline \multirow[t]{2}{*}{ Phenotype } & \multirow[t]{2}{*}{ Culture fraction } & \multicolumn{2}{|c|}{$q \mathrm{Cu}^{2+}$} & \multicolumn{2}{|c|}{$q \mathrm{~Pb}^{2+}$} & \multicolumn{2}{|c|}{$\begin{array}{l}\text { Inhibition of metal } \\
\text { sorption }(\%)^{\star}\end{array}$} \\
\hline & & Mono-metal & Bi-metal & Mono-metal & Bi-metal & $\mathrm{Cu}^{2+}$ & $\mathbf{P b}^{2+}$ \\
\hline Wild-type $\dagger$ & Whole culture & $25.76 \pm 1.44$ & $13.60 \pm 0.61$ & $44.03 \pm 0.72$ & $37.95 \pm 3.10$ & 47.2 & 13.8 \\
\hline Mutant $\dagger$ & Whole culture & $43.80 \pm 1.70$ & $15.15 \pm 1.81$ & $108.21 \pm 1.10$ & $65.10 \pm 8.36$ & 65.4 & 39.8 \\
\hline Wild-type $\neq$ & Whole culture & $76.54 \pm 11.30$ & $41.65 \pm 2.85$ & $131.41 \pm 14.00$ & $110.66 \pm 3.11$ & 47.2 & 13.8 \\
\hline \multirow[t]{3}{*}{ Mutant $\ddagger$} & Whole culture & $88.88 \pm 5.93$ & $34.46 \pm 6.88$ & $225.63 \pm 17.11$ & $134.66 \pm 25.46$ & 65.4 & 39.8 \\
\hline & Isolated biomass & $43.71 \pm 3.58$ & $<0.005 \S$ & $147.70 \pm 53.18$ & $29.90 \pm 13.99$ & 100.0 & 79.8 \\
\hline & Isolated RPS & $92.38 \pm 26.16$ & $26.50 \pm 5.60$ & $237.05 \pm 47.28$ & $138.33 \pm 24.96$ & 71.3 & 41.6 \\
\hline
\end{tabular}

${ }^{*}$ Inhibition in bi-metal solutions compared with the $q$ value obtained in mono-metal solutions.

$\dagger$ Specific metal removal expressed as (mg metal removed) ( $\mathrm{g}$ dry weight $)^{-1}$.

$¥$ Specific metal removal expressed as (mg metal removed) ( $\mathrm{g}$ total carbohydrates) ${ }^{-1}$.

$\S$ Detection limit of the instrument.

the order in which the biomasses were exposed to the metals, aliquots of the first metal were always released into the second solution, and part of the second metal was bound to the biosorbent. However, when the biomasses were transferred from the $\mathrm{Pb}^{2+}$ to the $\mathrm{Cu}^{2+}$ solution, 37.3 and $18.6 \%$ of the already adsorbed $\mathrm{Pb}^{2+}$ was released into the second solution by the wild-type and mutant, respectively. In contrast, in the reverse situation, the values of $\mathrm{Cu}^{2+}$ desorption were 38.9 and $48.0 \%$ for the wild-type and mutant, respectively.

\section{DISCUSSION}

The data obtained revealed significant differences in the growth of Gloeothece wild-type and its sheathless mutant. While the mutant shows a typical bacterial growth curve, the wild-type does not exhibit a clear exponential phase.
This type of linear growth is not unknown for cyanobacteria, particularly for strains that produce large amounts of structured extracellular polysaccharides, and may be related to the considerable amount of energy spent in the production of EPS and the physical constraints caused by these extracellular complex structures (Yu et al., 2009, 2010).

The higher tolerance exhibited by Gloeothece wild-type and mutant for $\mathrm{Pb}^{2+}$ strongly indicates that these organisms are more severely affected by $\mathrm{Cu}^{2+}$ than by $\mathrm{Pb}^{2+}$. The differences observed are probably related to the specific nutritional requirements and mechanisms of metal uptake and accumulation in the cells (Nies, 2003; Rosen, 2002; Rensing et al., 1999). Copper is an essential micronutrient for all organisms, functioning as a cofactor and being required for structural and catalytic properties of enzymes such as the copper/zinc superoxide dismutase (Burnat et al.,

Table 2. Specific metal removal $(q)$ and metal desorption from mono-metal solutions using isolated biomass cultures of Gloeothece sp. PCC 6909 (wild-type) or Gloeothece sp. CCY 9612 (sheathless mutant)

Data are means $\pm \operatorname{SD}(n=3)$.

\begin{tabular}{|lccccc|}
\hline Phenotype & \multicolumn{3}{c|}{$\mathbf{C u}^{2+}$} & & \multicolumn{2}{c|}{$\mathbf{P b}^{2+}$} \\
\cline { 2 - 5 } & $\boldsymbol{q}^{*}$ & Desorption $\dagger$ & $\boldsymbol{q}^{*}$ & Desorption $\dagger$ \\
\hline Wild-type & $90.61 \pm 9.69$ & $35.25 \pm 4.37(38.9)$ & & $144.59 \pm 7.26$ & $53.90 \pm 4.06(37.3)$ \\
Mutant & $44.38 \pm 6.99$ & $21.09 \pm 0.67(48.0)$ & & $139.38 \pm 2.72$ & $25.91 \pm 4.10(18.6)$ \\
\hline
\end{tabular}

${ }^{*}$, , specific metal removal expressed as (mg metal removed) (g total carbohydrates) ${ }^{-1}$.

$\dagger$ Values in parentheses indicate the percentage of metal removed from the first metal solution and subsequently desorbed into the second solution (containing the other metal). 
2009). In cyanobacteria, copper is also a cofactor of the electron transport protein plastocyanin and other proteins associated with thylakoids, which imposes an extra complexity to copper homeostasis in these organisms compared with non-photosynthetic prokaryotes (Cavet et al., 2003; De la Cerda et al., 2007; Shcolnick \& Keren, 2006). However, excessive amounts of copper have been reported to cause serious damage to photosynthetic cells (Stuart et al., 2009) due to (i) the formation of reactive oxygen species, mainly hydroxyl radicals, which can damage several cellular components (Gaetke \& Chow, 2003), (ii) competitive binding to metal transporters inhibiting the uptake of other essential metals (Sunda \& Huntsman, 1998) and (iii) the inhibition of photosynthetic electron transport especially in PSII (Baron et al., 1995). On the other hand, lead is a non-redox-active metal with no known biological function, and its toxicity has been associated with indirect effects such as the ability to mimic essential metals, the inhibition of the photosynthetic electron transport, mainly at the PSII reaction centre, and reduction of the cellular antioxidants pool (Burnat et al., 2009; Chaloub et al., 2005; Pinchasov et al., 2006; Pinto et al., 2003; Xiong, 1998).

Although both phenotypes were more severely affected by $\mathrm{Cu}^{2+}$ than by $\mathrm{Pb}^{2+}$, the mutant was shown to be even more sensitive. Moreover, the extended lag phase and the time needed for recovery observed for the mutant in $\mathrm{Cu}^{2+}$ supplemented medium is consistent with the activation of a specific detoxification mechanism(s). The absence of this phenomenon in the wild-type and the difference in the growth rates observed for the two phenotypes highlight major differences in central metabolic processes rather than only the presence/absence of the structure sheath. This could be expected for a mutant obtained by random mutagenesis and it has been confirmed by proteomic studies (S. Pereira and others, unpublished). The lower sensitivity to $\mathrm{Cu}^{2+}$ and the higher metal removal capability exhibited by the isolated biomass of the wild-type compared with the mutant, together with the accumulation of $\mathrm{Cu}^{2+}$ on the sheath, suggest that the presence of a structured envelope prevents, at least partially, the entry of this metal into the cell. In all situations, the total carbohydrate content of the cultures varied in parallel with the $\mathrm{OD}$ values, indicating that the presence of a metal(s) did not inhibit or stimulate the production of EPS.

TEM studies confirmed the higher toxicity of $\mathrm{Cu}^{2+}$, and the ultrastructural damage observed when the cells are exposed to high metal concentrations $\left(10 \mathrm{mg} \mathrm{l}^{-1}\right)$ is in agreement with previous studies that reported membrane disorganization as a common cyanobacterial response to metal toxicity (Arunakumara et al., 2008). The high number of intracellular inclusions observed in cells exposed to sublethal concentrations of $\mathrm{Pb}^{2+}$ or $\mathrm{Cu}^{2+}$, as well as their characteristic sublimation under the electron beam, strongly suggest that they are polyphosphate bodies (PPB) (Jensen, 1968; Jensen et al., 1977). In fact, it has been previously suggested that $\mathrm{PPB}$, as well as functioning as phosphorus storage and an energy source, could also be involved in the sequestration of metal ions and their detoxification (Allen, 1984; Jensen et al., 1982; Rachlin et al., 1982; Surosz \& Palinska, 2005). The high amount of PPB in the cells could explain the growth recovery of the mutant after the extended lag phase that occurs in the presence of high concentrations of $\mathrm{Cu}^{2+}$. The presence of electron-dense deposits in the cytoplasm of both the wildtype and mutant cells exposed to $\mathrm{Cu}^{2+}$ is probably related to the existence of a specific transport system related to the demand of this element for proteins located at/in the thylakoids. It is known that cyanobacteria possess two different P-type ATPases, CtaA and PacS, which transport copper across the plasma and thylakoidal membranes, respectively (Baptista \& Vasconcelos, 2006; De la Cerda et al., 2007).

Since the binding of metal ions to EPS can prevent, up to a point, the entrance of the metals into the cells, it will also affect the metal homeostasis in these organisms (Baptista \& Vasconcelos, 2006; Nies, 1999). In all experiments, $\mathrm{Pb}^{2+}$ was preferentially removed compared with $\mathrm{Cu}^{2+}$, in agreement with observations from previous work using different biological materials such as cyanobacteria, algae, fungi and plants (Can \& Jianlong, 2007; Hawari \& Mulligan, 2007; Singh et al., 2000, 2007; Zhang \& Banks, 2006). This phenomenon can be explained by the Pearson's hard-soft acid base theory, in which the biosorbent acts as a Lewis base and the metal acts as a Lewis acid. According to this theory, metals ions are classified as class A (hard acids), class B (soft acids) or borderline, according to their affinity for different ligands (Pearson, 1963, 1968). Both $\mathrm{Pb}^{2+}$ and $\mathrm{Cu}^{2+}$ are borderline (Nieboer \& Richardson, 1980; Pearson, 1968). However, due to the higher values of electronegativity and radius of $\mathrm{Pb}^{2+}$ (2.33 and $1.18 \AA$, respectively, compared with 1.90 and $0.73 \AA$ for $\left.\mathrm{Cu}^{2+}\right)$, its covalent index, calculated as $X_{\mathrm{m}}{ }^{2} r$ (in which $X_{\mathrm{m}}$ is the electronegativity and $r$ is the radius of the metal ion), is higher than that of $\mathrm{Cu}^{2+}$, which increases its affinity for the EPS binding sites (Can \& Jianlong, 2007; Hawari \& Mulligan, 2007; Nieboer \& Richardson, 1980).

The larger amounts of $\mathrm{Pb}^{2+}$ that remain sequestered in the EPS of Gloeothece may contribute to the higher tolerance observed for this metal, by decreasing the amount that enters the cells. However, in the case of the wild-type, the binding of large amounts of $\mathrm{Pb}^{2+}$ to its sheath may also affect the transit of nutrients into the cell, causing a more significant decrease in the growth rate compared with the mutant. Although $\mathrm{Pb}^{2+}$ is a non-essential metal, it seems that it can accumulate in vacuolar structures inside the cells, as observed in TEM studies. The mechanisms by which $\mathrm{Pb}^{2+}$ enters the cyanobacterial cells are not yet fully elucidated, although P-type ATPases involved in the transmembrane transport (uptake and/or efflux) of $\mathrm{Zn}^{2+}$, $\mathrm{Cd}^{2+}$ and $\mathrm{Pb}^{2+}$ have been identified in some strains (Baptista \& Vasconcelos, 2006). 
The higher efficiency of metal removal observed for the whole cultures and isolated RPS of the mutant compared with the wild-type shows that the role of the sheath in metal binding is limited, and that the increased metal binding efficiency of the mutant can mainly be ascribed to its RPS. In fact, the RPS of the mutant contain higher amounts of acidic sugars, which increases their affinity towards metal cations, and possess a smaller amount of deoxysugars, which increases their solubility and, thus, their accessibility to the metal cations. Furthermore, the mutant's RPS were shown to possess a higher number and/ or more accessible carboxyl and amide functional groups, which are the most important metal binding sites in Gloeothece, as demonstrated by Micheletti et al. (2008b).

In the presence of more than one metal, the process of metal binding to the cyanobacterial EPS can be noninteractive, synergistic or competitive, depending on the metal ions and characteristics of the polysaccharide (Micheletti et al., 2008a). In the present study, the results obtained in the bi-metal systems unveiled a mutual inhibition in the adsorption of $\mathrm{Cu}^{2+}$ and $\mathrm{Pb}^{2+}$, as the presence of one metal inhibited, at least partially, the adsorption of the other. This mutual inhibition can result from (i) direct competition between the two metals for the EPS binding sites and/or (ii) modification of the EPS conformation by the already adsorbed metal ions, which will hinder the access of other ions to adjacent adsorption sites (Micheletti et al., 2008a; Parker et al., 2000). The higher inhibition of $\mathrm{Cu}^{2+}$ adsorption in the presence of $\mathrm{Pb}^{2+}$ supports the higher affinity of these EPS for $\mathrm{Pb}^{2+}$. This hypothesis is further confirmed by the lower values of $\mathrm{Pb}^{2+}$ desorption compared with $\mathrm{Cu}^{2+}$ in bi-metal systems, especially considering that both solutions contained $10 \mathrm{mg}$ metal $1^{-1}$ and thus, due to their atomic weights, the molarity is 3.25 times higher for $\mathrm{Cu}^{2+}$. Furthermore, in the presence of both metals, the higher affinity towards $\mathrm{Pb}^{2+}$ probably reduced the amount of $\mathrm{Cu}^{2+}$ entering the cells and partially protected them from the harmful effects of this metal.

In conclusion, this study confirms that the simultaneous presence of two metals in aqueous solution may cause a mutual inhibition in the adsorption of each metal to the EPS, emphasizing the need to select a specific cyanobacterial strain/EPS for a given metal-containing effluent. Moreover, depending on the metal(s) concentration(s) and its toxic effects, it may also be necessary to assess the advantages/disadvantages of using whole cultures versus isolated EPS. In this particular case, RPS, which are the most efficient fraction in the metal adsorption, can be easily separated from the cultures and immobilized or confined for biotechnological applications.

\section{ACKNOWLEDGEMENTS}

This work was supported by Fundação Calouste Gulbenkian: Programa Ambiente e Saúde; Proc. 76910, FCT (SFRH/BD/22733/ 2005 and SFRH/BPD/37045/2007), POCI 2010 (III Quadro
Comunitário de Apoio) and Acordo de Cooperação Científica e Tecnológica GRICES/CNR, Proc. 4.1.1., 2007.

\section{REFERENCES}

Allen, M. M. (1984). Cyanobacterial cell inclusions. Annu Rev Microbiol 38, 1-25.

Arunakumara, K. K. I. U., Zhang, X. \& Song, X. (2008). Bioaccumulation of $\mathrm{Pb}^{2+}$ and its effects on growth, morphology and pigment contents of Spirulina (Arthrospira) platensis. J Ocean Univ China 7, 397-403.

Baptista, M. S. \& Vasconcelos, M. T. (2006). Cyanobacteria metal interactions: requirements, toxicity, and ecological implications. Crit Rev Microbiol 32, 127-137.

Baron, J., Arellano, J. B. \& Gorge, J. L. (1995). Copper and photosystem II: a controversial relationship. Physiol Plant 94, 174-180.

Burnat, M., Diestra, E., Esteve, I. \& Sole, A. (2009). In situ determination of the effects of lead and copper on cyanobacterial populations in microcosms. PLoS ONE 4, e6204.

Can, C. \& Jianlong, W. (2007). Correlating metal ionic characteristics with biosorption capacity using QSAR model. Chemosphere 69, 16101616.

Cavet, J. S., Borrelly, G. P. M. \& Robinson, N. J. (2003). Zn, Cu and Co in cyanobacteria: selective control of metal availability. FEMS Microbiol Rev 27, 165-181.

Chaloub, R. M., de Magalhães, C. C. P. \& dos Santos, C. P. (2005). Early toxic effects of zinc on PSII of Synechocystis aquatilis $f$. aquatilis (Cyanophyceae). J Phycol 41, 1162-1168.

De la Cerda, B., Castielli, O., Durán, R. V., Navarro, J. A., Hervás, M. \& De la Rosa, M. A. (2007). A proteomic approach to iron and copper homeostasis in cyanobacteria. Brief Funct Genomic Proteomic 6, 322329.

De Philippis, R. \& Micheletti, E. (2009). Heavy metal removal with exopolysaccharide-producing cyanobacteria. In Heavy Metals in the Environment, pp. 89-122. Edited by L. K. Wang, J. P. Chen, Y.-T. Hung \& N. K. Shammas. Boca Raton, USA: CRC Press.

De Philippis, R. \& Vincenzini, M. (2003). Outermost polysaccharidic investments of cyanobacteria: nature, significance and possible applications. Recent Res Dev Microbiology 7, 13-22.

De Philippis, R., Sili, C., Paperi, R. \& Vincenzini, M. (2001). Exopolysaccharide-producing cyanobacteria and their possible exploitation: a review. J Appl Phycol 13, 293-299.

De Philippis, R., Paperi, R. \& Sili, C. (2007). Heavy metal sorption by released polysaccharides and whole cultures of two exopolysaccharide-producing cyanobacteria. Biodegradation 18, 181-187.

Dubois, M., Gilles, K. A., Hamilton, J. K., Rebers, P. A. \& Smith, F. (1956). Colorimetric method for determination of sugars and related substances. Anal Chem 28, 350-356.

Fiore, M. F. \& Trevors, J. T. (1994). Cell composition and metal tolerance in cyanobacteria. Biometals 7, 83-103.

Gaetke, L. M. \& Chow, C. K. (2003). Copper toxicity, oxidative stress, and antioxidant nutrients. Toxicology 189, 147-163.

Hawari, A. H. \& Mulligan, C. N. (2007). Effect of the presence of lead on the biosorption of copper, cadmium and nickel by anaerobic biomass. Process Biochem 42, 1546-1552.

Heng, L. Y., Jusoh, K., Ling, C. H. M. \& Idris, M. (2004). Toxicity of single and combinations of lead and cadmium to the cyanobacteria Anabaena flos-aquae. Bull Environ Contam Toxicol 72, 373-379.

Ishaque, A. B., Johnson, L., Gerald, T., Boucaud, D., Okoh, J. \& Tchounwou, P. B. (2006). Assessment of individual and combined 
toxicities of four non-essential metals ( $\mathrm{As}, \mathrm{Cd}, \mathrm{Hg}$ and $\mathrm{Pb}$ ) in the microtox assay. Int J Environ Res Public Health 3, 118-120.

Jensen, T. E. (1968). Electron microscopy of polyphosphate bodies in a blue-green alga, Nostoc pruniforme. Arch Microbiol 62, 144-152.

Jensen, T. E., Sicko-Goad, L. \& Ayala, R. P. (1977). Phosphate metabolism in blue-green algae. III. The effect of fixation and poststaining on the morphology of polyphosphate bodies in Plectonema boryanum. Cytologia (Tokyo) 42, 357-369.

Jensen, T. E., Baxter, M., Rachlin, J. W. \& Jani, V. (1982). Uptake of heavy metals by Plectonema boryanum (Cyanophyceae) into cellular components, especially polyphosphate bodies: an X-ray energy dispersive study. Environ Pollut 27, 119-127.

Kiran, B., Kaushik, A. \& Kaushik, C. P. (2008). Metal-salt co-tolerance and metal removal by indigenous cyanobacterial strains. Process Biochem 43, 598-604.

Leitão, E., Oxelfelt, F., Oliveira, P., Moradas-Ferreira, P. \& Tamagnini, P. (2005). Analysis of the hupSL operon of the nonheterocystous cyanobacterium Lyngbya majuscula CCAP 1446/4: regulation of transcription and expression under a light-dark regime. Appl Environ Microbiol 71, 4567-4576.

Lewinson, O., Lee, A. T. \& Rees, D. C. (2009). A P-type ATPase importer that discriminates between essential and toxic transition metals. Proc Natl Acad Sci U S A 106, 4677-4682.

Li, P., Harding, S. E. \& Liu, Z. (2001). Cyanobacterial exopolysaccharides: their nature and potential biotechnological applications. Biotechnol Genet Eng Rev 18, 375-404.

Micheletti, E., Colica, G., Viti, C., Tamagnini, P. \& De Philippis, R. (2008a). Selectivity in the heavy metal removal by exopolysaccharideproducing cyanobacteria. J Appl Microbiol 105, 88-94.

Micheletti, E., Pereira, S., Mannelli, F., Moradas-Ferreira, P., Tamagnini, P. \& De Philippis, R. (2008b). Sheathless mutant of the cyanobacterium Gloeothece sp. strain PCC 6909 with increased capacity to remove copper ions from aqueous solutions. Appl Environ Microbiol 74, 2797-2804.

Nieboer, E. \& Richardson, D. H. S. (1980). The replacement of the nondescript term "heavy metals" by a biologically and chemically significant classification of metal ions. Environ Pollut Ser 1, 3-26.

Nies, D. H. (1999). Microbial heavy-metal resistance. Appl Microbiol Biotechnol 51, 730-750.

Nies, D. H. (2003). Eflux-mediated heavy metal resistance in prokaryotes. FEMS Microbiol Rev 27, 313-339.

Parker, D. L., Mihalick, J. E., Plude, J. L., Plude, M. J., Clark, T. P., Egan, L., Flom, J. J., Rai, L. C. \& Kumar, H. D. (2000). Sorption of metals by extracellular polymers from the cyanobacterium Microcystis aeruginosa f. flos-aquae strain C3-40. J Appl Phycol 12, 219-224.

Pearson, R. G. (1963). Hard and soft acids and bases. J Am Chem Soc 85, 3533-3539.

Pearson, R. G. (1968). Hard and soft acids and bases, HSAB, part 1: fundamental principles. J Chem Educ 45, 581.

Pereira, S., Zille, A., Micheletti, E., Moradas-Ferreira, P., De Philippis, R. \& Tamagnini, P. (2009). Complexity of cyanobacterial exopolysaccharides: composition, structures, inducing factors, and putative genes involved in their biosynthesis and assembly. FEMS Microbiol Rev 33, 917-941.

Pinchasov, Y., Berner, T. \& Dubinsky, Z. (2006). The effect of lead on photosynthesis, as determined by photoacoustics in Synechococcus leopoliensis (Cyanobacteria). Water Air Soil Pollut 175, 117-125.

Pinto, E., Sigaud-kutner, T. C. S., Leitão, M. A. S., Okamoto, O. K., Morse, D. \& Colepicolo, P. (2003). Heavy metal-induced oxidative stress in algae. J Phycol 39, 1008-1018.
Rachlin, J. W., Jensen, T. E., Baxter, M. \& Jani, V. (1982). Utilization of morphometric analysis in evaluating response of Plectonema boryanum (Cyanophyceae) to exposure to eight heavy metals. Arch Environ Contam Toxicol 11, 323-333.

Rensing, C., Ghosh, M. \& Rosen, B. P. (1999). Families of soft-metalion-transporting ATPases. J Bacteriol 181, 5891-5897.

Rippka, R., Deruelles, J., Waterbury, J. B., Herdman, M. \& Stanier, R. Y. (1979). Generic assignments, strain histories and properties of pure cultures of cyanobacteria. J Gen Microbiol 111, 1-61.

Rosen, B. P. (2002). Transport and detoxification systems for transition metals, heavy metals and metalloids in eukaryotic and prokaryotic microbes. Comp Biochem Physiol A Mol Integr Physiol 133, 689-693.

Roy, S., Ghosh, A. N. \& Thakur, A. R. (2008). Uptake of $\mathrm{Pb}^{2+}$ by a cyanobacterium belonging to the genus Synechocystis, isolated from East Kolkata Wetlands. Biometals 21, 515-524.

Seabra, R., Santos, A., Pereira, S., Moradas-Ferreira, P. \& Tamagnini, P. (2009). Immunolocalization of the uptake hydrogenase in the marine cyanobacterium Lyngbya majuscula CCAP 1446/4 and two Nostoc strains. FEMS Microbiol Lett 292, 57-62.

Shcolnick, S. \& Keren, N. (2006). Metal homeostasis in cyanobacteria and chloroplasts. Balancing benefits and risks to the photosynthetic apparatus. Plant Physiol 141, 805-810.

Singh, S., Pradhan, S. \& Rai, L. C. (2000). Metal removal from single and multimetallic systems by different biosorbent materials as evaluated by differential pulse anodic stripping voltammetry. Process Biochem 36, 175-182.

Singh, A., Kumar, D. \& Gaur, J. P. (2007). Copper(II) and lead(II) sorption from aqueous solution by non-living Spirogyra neglecta. Bioresour Technol 98, 3622-3629.

Stuart, R. K., Dupond, C. L., Johnson, D. A., Paulsen, I. T. \& Palenik, B. (2009). Coastal strains of marine Synechococcus species exhibit increased tolerance to copper shock and a distinctive transcriptional response relative to those of open-ocean strains. Appl Environ Microbiol 75, 5047-5057.

Sunda, W. G. \& Huntsman, S. A. (1998). Interactions among $\mathrm{Cu}^{2+}$, $\mathrm{Zn}^{2+}$, and $\mathrm{Mn}^{2+}$ in controlling cellular $\mathrm{Mn}, \mathrm{Zn}$, and growth rate in the coastal alga Chlamydomonas. Limnol Oceanogr 43, 1055-1064.

Surosz, W. \& Palinska, K. A. (2005). Effects of heavy-metal stress on cyanobacterium Anabaena flos-aquae. Arch Environ Contam Toxicol 48, 40-48.

Valls, M. \& de Lorenzo, V. (2002). Exploiting the genetic and biochemical capacities of bacteria for the remediation of heavy metal pollution. FEMS Microbiol Rev 26, 327-338.

Volesky, B. \& May-Phillips, H. A. (1995). Biosorption of heavy metals by Saccharomyces cerevisiae. Appl Microbiol Biotechnol 42, 797-806.

Xiong, Z.-T. (1998). Lead uptake and effects on seed germination and plant growth in a $\mathrm{Pb}$ hyperaccumulator Brassica pekinensis Rupr. Bull Environ Contam Toxicol 60, 285-291.

Yu, H., Jia, S. \& Dai, Y. (2009). Growth characteristics of the cyanobacterium Nostoc flagelliforme in photoautotrophic, mixotrophic and heterotrophic cultivation. J Appl Phycol 21, 127-133.

Yu, H., Jia, S. \& Dai, Y. (2010). Accumulation of exopolysaccharides in liquid suspension culture of Nostoc flagelliforme cells. Appl Biochem Biotechnol 160, 552-560.

Zhang, Y. \& Banks, C. (2006). A comparison of the properties of polyurethane immobilised Sphagnum moss, seaweed, sunflower waste and maize for the biosorption of $\mathrm{Cu}, \mathrm{Pb}, \mathrm{Zn}$ and $\mathrm{Ni}$ in continuous flow packed columns. Water Res 40, 788-798.

Edited by: D. H. Nies 